\title{
Temperature affects the early life history stages of corals more than near future ocean acidification
}

\author{
Chia Miin Chua ${ }^{1, *}$, William Leggat ${ }^{1,2}$, Aurelie Moya ${ }^{1,3,4}$, Andrew H. Baird ${ }^{1}$ \\ ${ }^{1}$ ARC Centre of Excellence for Coral Reef Studies and ${ }^{2}$ School of Pharmacy and Molecular Sciences, James Cook University, \\ Townsville, Queensland, 4811, Australia \\ ${ }^{3}$ INSU-CNRS, Laboratoire d'Océanographie de Villefranche, B.P. 28, 06234 Villefranche-sur-mer Cedex, France \\ ${ }^{4}$ UPMC University of Paris 06, Observatoire Océanologique de Villefranche, 06230 Villefranche-sur-mer, France
}

\begin{abstract}
Climate change is projected to increase ocean temperatures by at least $2{ }^{\circ} \mathrm{C}$, and levels of $\mathrm{pH}$ by $\sim 0.2$ units (ocean acidification, $\mathrm{OA}$ ) by the end of this century. While the effects of these stressors on marine organisms have been relatively well explored in isolation, possible interactions between temperature and OA have yet to be thoroughly investigated. OA at levels projected to occur within this century has few direct ecological effects on the early life history stages of corals. In contrast, temperature has pronounced effects on many stages in the early life history of corals. Here, we test whether temperature might act in combination with OA to produce a measurable ecological effect on fertilization, development, larval survivorship or metamorphosis of 2 broadcast spawning species, Acropora millepora and A. tenuis, from the Great Barrier Reef. We used 4 treatments: control, high temperature $\left(+2^{\circ} \mathrm{C}\right)$, high partial pressure of $\mathrm{CO}_{2}\left(\mathrm{pCO}_{2}\right)$ (700 $\mu \mathrm{atm}$ ) and a combination of high temperature and high $\mathrm{pCO}_{2}$, corresponding to the current levels of these variables and the projected values for the end of this century under the IPCC A2 scenario. We found no consistent effect of elevated $\mathrm{pCO}_{2}$ on fertilization, development, survivorship or metamorphosis, neither alone nor in combination with temperature. In contrast, a $2^{\circ} \mathrm{C}$ rise in temperature increased rates of development, but otherwise had no consistent effect on fertilization, survivorship or metamorphosis. We conclude that OA is unlikely to be a direct threat to the early life history stages of corals, at least in the near future. In contrast, rising sea temperatures are likely to affect coral population dynamics by increasing the rate of larval development with resulting changes in patterns of connectivity.
\end{abstract}

KEY WORDS: Coral reefs - Climate change - Connectivity - Development - Larval ecology · Survivorship $\cdot$ Settlement Resale or republication not permitted without written consent of the publisher

\section{INTRODUCTION}

Increasing carbon dioxide $\left(\mathrm{CO}_{2}\right)$ concentrations in the atmosphere are causing the oceans to warm. Sea surface temperatures have risen by a global average of $0.7^{\circ} \mathrm{C}$ since the industrial revolution (Feely et al. 2009) and are predicted to rise by a further 2 to $3^{\circ} \mathrm{C}$ by the end of the century under the IPCC A2 scenario (Bindoff et al. 2007). In addition, the absorption of atmospheric $\mathrm{CO}_{2}$ is changing ocean chemistry, decreasing seawater $\mathrm{pH}$ and reducing the availability of carbonate ions $\left(\mathrm{CO}_{3}{ }^{2-}\right)$. Ocean $\mathrm{pH}$ has decreased by 0.1 units since the $1950 \mathrm{~s}$ and is projected to decrease by a further 0.2 to 0.3 units by the end of the century (Feely et al. 2009).

The effects of rising sea surface temperature on marine organisms are well documented. Symbiotic organisms, such as corals, seem particularly sensitive to elevated temperatures (Baird et al. 2009), and the resulting coral bleaching has a range of ecological effects from reductions in growth, reproduction and competitive ability to high mortality of individuals over large spatial scales (see review in McClanahan et al. 2009). In contrast, the effects of ocean acidi- 
fication (OA) are less obvious, in part because the effects are often sub-lethal (Fabricius et al. 2011). Early experiments suggested a linear decline in calcification in response to a declining aragonite saturation state (Langdon \& Atkinson 2005); however, more recent work indicates that the response is highly variable among species and dependent upon experimental techniques (see review in Pandolfi et al. 2011).

The effects of temperature on the early life history stages of coral are also well documented. For example, temperature increases of 1 to $2^{\circ} \mathrm{C}$ above ambient levels result in high numbers of abnormally developed larvae (Bassim et al. 2002, Negri et al. 2007). Similarly, high temperatures reduce larval survivorship (Baird et al. 2006), particularly in larvae that contain symbiotic algae (Yakovleva et al. 2009, Nesa et al. 2012). In contrast, the effects of OA on coral larval ecology are much more variable and direct effects are only evident at very high partial pressure of $\mathrm{CO}_{2}$ $\left(\mathrm{pCO}_{2}\right)$ levels or when gametes and larvae are past their peak (see review in Dufault et al. 2012).

In the wild, these 2 stressors clearly act on organisms simultaneously; however, there have been very few experiments that explore the combined effects of high $\mathrm{pCO}_{2}$ and temperature. The general assumption is that the effect of $\mathrm{OA}$ and temperature will be additive. Indeed, high $\mathrm{pCO}_{2}$ in combination with high temperature lowers thermal bleaching thresholds in corals and crustose coralline algae (Anthony et al. 2008). Similarly, growth rates of Porites panamensis juveniles were lowest in a combined high $\mathrm{pCO}_{2}$ and high temperature treatment (Anlauf et al. 2011). However, the interaction could be antagonistic because temperature increases metabolism (O'Connor et al. 2009), and high $\mathrm{pCO}_{2}$ reduces it (Pörtner et al. 2004). In another example, high temperatures can compensate for dwarfism that would otherwise eventuate due to reduced calcification in acidified sea water, as in Tripneustes gratilla larvae (Sheppard Brennand et al. 2010).

In this study, we tested the combined effects of elevated temperature and elevated $\mathrm{pCO}_{2}$ on the early life history stages of 2 common spawning acroporids of the northern Great Barrier Reef region.

\section{MATERIALS AND METHODS}

\section{Collection of mature colonies}

Six mature colonies of Acropora tenuis and A. millepora were collected at Magnetic Island $\left(19^{\circ} 9^{\prime} \mathrm{S}\right.$, $146^{\circ} 50^{\prime} \mathrm{E}$ ) and a second batch of 6 A. millepora colonies were collected from Orpheus Island $\left(18^{\circ} 35^{\prime} \mathrm{S}\right.$, $146^{\circ} 29^{\prime} \mathrm{E}$ ), a few days prior to the predicted spawning period in 2010. They were transported to James Cook University and maintained in outdoor aquaria (GBRMPA permit: G10/33174.1). A. tenuis spawned on the night of 28 October 2010; A. millepora from Magnetic Island spawned on the nights of 1 and 2 November 2010. A. millepora colonies from Orpheus Island spawned on 22 and 30 November 2010. Consequently, 6 cohorts of larvae were available for the experiments: $A$. tenuis, A. millepora Nov_1, A. millepora Nov_2, A. millepora Nov_22 and A. millepora Nov_30. However, not all response variables were tested in each of these cohorts.

\section{Experiments on ocean acidification and warming}

The $\mathrm{CO}_{2}$ tanks were located in a temperature controlled room $\left(27^{\circ} \mathrm{C}\right)$. Two levels of $\mathrm{CO}_{2}$ concentration (ambient and elevated $\mathrm{pCO}_{2}$ ) and 2 levels of temperature (ambient $27^{\circ} \mathrm{C}$ and $29^{\circ} \mathrm{C}$ ) were selected as recommended by the European Project on Ocean Acidification (EPOCA) protocol (Barry et al. 2010). The 4 treatments were (1) ambient temperature + ambient pCO2, (2) ambient temperature + high pCO2, (3) high temperature + ambient pCO2, (4) high temperature + high pCO2 (see Table 1 for mean values of each level of each factor used in the experiments).

Experimental temperatures were maintained using aquarium heaters (Eheim Jäger 300W placed in water baths and bath temperatures were measured twice daily. The desired $\mathrm{pCO}_{2}$ level in the sea water was produced using a $\mathrm{CO}_{2}$ mixing system developed by Munday et al. (2009) and the $\mathrm{pCO}_{2}$ concentration was measured in ppm units using a $\mathrm{CO}_{2}$ gas probe (Vaisala ${ }^{\circledR}$ ). The mixed gases were bubbled through 2501 sump tanks and water chemistry parameters and corresponding total alkalinity (TA) were measured for each treatment throughout the experiment (Table 1) by using a fixed end point titration method. Experimental calcite $\left(\Omega_{\text {calc }}\right)$ and aragonite saturations $\left(\Omega_{\text {arag }}\right)$, as well as actual $\mathrm{pCO}_{2}$ ( $\left.\mu \mathrm{atm}\right)$ were calculated from average total alkalinity data (TA), salinity, temperature and pHNBS using CO2SYS with dissociation constants of Mehrbach et al. (1973) as refitted by Dickson \& Millero (1987) (Pierrot et al. 2006). Dissolved oxygen (DO\% saturated) was measured daily to ensure sufficient oxygen flow in the treatment tanks.

\section{The effect of temperature and $\mathrm{pCO}_{2}$ on fertilization}

Egg and sperm bundles were collected from individual colonies, mixed and then gently agitated to 
Table 1. Water chemistry parameters (means $\pm \mathrm{SE}$ ) for experiments with (1) Acropora tenuis, A. millepora Nov_01 and A. millepora Nov_02, and (2) with $A$. millepora Nov_22 and $A$. millepora Nov_30. Saturation values of aragonite ( $\left.\Omega_{\text {arag }}\right)$ and calcite $\left(\Omega_{\text {calc }}\right)$ and actual saturated values of $\mathrm{pCO}_{2}$ in treatments tanks calculated using CO2SYS (Pierrot et al. 2006)

\begin{tabular}{|c|c|c|c|c|c|c|}
\hline Treatment & $\mathrm{pH}$ & $\begin{array}{l}\text { Total alkalinity } \\
\left(\mu \mathrm{mol} \mathrm{kg}{ }^{-1}\right. \\
\left.\text { as } \mathrm{CaCO}_{3}\right)\end{array}$ & Temp $\left({ }^{\circ} \mathrm{C}\right)$ & $\Omega_{\text {calc }}$ & $\Omega_{\text {arag }}$ & $\begin{array}{c}\mathrm{pCO}_{2} \\
\text { calculated } \\
\quad(\mu \mathrm{atm})\end{array}$ \\
\hline \multicolumn{7}{|c|}{ (1) A. tenuis, A. millepora Nov_01 and A. millepora Nov_02 } \\
\hline Ambient temp + Ambient $\mathrm{pCO}_{2}$ & $8.17 \pm 0.01$ & $2205 \pm 19$ & $25.7 \pm 0.13$ & $4.8 \pm 0.1$ & $3.2 \pm 0.1$ & $421 \pm 10$ \\
\hline High temp + Ambient $\mathrm{pCO}_{2}$ & $8.18 \pm 0.01$ & $2232 \pm 9$ & $28.5 \pm 0.10$ & $4.7 \pm 0.1$ & $3.2 \pm 0.1$ & $499 \pm 9$ \\
\hline Ambient temp + High $\mathrm{pCO}_{2}$ & $8.06 \pm 0.02$ & $2111 \pm 44$ & $25.6 \pm 0.12$ & $3.3 \pm 0.1$ & $2.2 \pm 0.1$ & $655 \pm 41$ \\
\hline High temp + High $\mathrm{pCO}_{2}$ & $8.06 \pm 0.01$ & $2162 \pm 54$ & $28.9 \pm 0.01$ & $2.8 \pm 0.3$ & $1.9 \pm 0.2$ & $663 \pm 20$ \\
\hline \multicolumn{7}{|c|}{ (2) A. millepora Nov_22 and A. millepora Nov_30 } \\
\hline Ambient temp + Ambient $\mathrm{pCO}_{2}$ & $8.12 \pm 0.01$ & $1947 \pm 14$ & $26.5 \pm 0.11$ & $3.7 \pm 0.2$ & $2.4 \pm 0.1$ & $474 \pm 34$ \\
\hline High temp + Ambient $\mathrm{pCO}_{2}$ & $8.12 \pm 0.01$ & $1955 \pm 21$ & $28.9 \pm 0.03$ & $3.7 \pm 0.2$ & $2.5 \pm 0.1$ & $521 \pm 43$ \\
\hline Ambient temp + High $\mathrm{pCO}_{2}$ & $7.98 \pm 0.02$ & $1920 \pm 25$ & $26.7 \pm 0.09$ & $2.7 \pm 0.2$ & $1.8 \pm 0.1$ & $699 \pm 34$ \\
\hline High temp + High $\mathrm{pCO}_{2}$ & $8.01 \pm 0.01$ & $1911 \pm 22$ & $29.2 \pm 0.11$ & $2.8 \pm 0.3$ & $1.9 \pm 0.2$ & $759 \pm 70$ \\
\hline
\end{tabular}

break up the bundles. Buoyant eggs were then separated from the sperm and a stock of sperm solution was prepared. We counted 20 eggs into each of 12 replicates of $25 \mathrm{ml}$ glass jars (6 with high $\mathrm{pCO}_{2}$ and 6 with ambient $\mathrm{pCO}_{2}$ seawater) and an equal quantity of sperm was introduced into each jar to produce a final concentration of $10^{6}$ sperm ml ${ }^{-1}$ to maximize the fertilization rate (Oliver \& Babcock 1992). Gametes were mixed within $30 \mathrm{~min}$ of spawning. The volume of sperm solution added was $<1 \mathrm{ml}$ and, therefore, unlikely to have influenced the $\mathrm{pH}$ levels in the jars. Then, 3 jars were placed in each of the 2 water baths containing heated water and 6 were kept at ambient temperature, resulting in 3 replicate jars in each of the 4 treatments. The number of cleaved embryos was quantified $2 \mathrm{~h}$ after the gametes were mixed to estimate fertilization rates. The cohorts used in these experiments are listed in the legend of Fig. 1.

\section{Effect of temperature and $\mathrm{pCO}_{2}$ on development}

Once cleavage was observed, embryos were washed 3 times in $0.2 \mu \mathrm{m}$ filtered sea water to remove excess sperm, which can cause cultures to deteriorate. Then, 1000 embryos were placed in each of 12 replicate 3.51 plastic jars, 3 jars per treatment, with $0.2 \mu \mathrm{m}$ filtered seawater at a flow rate of 1.5 to $2 \mathrm{l} \mathrm{h}^{-1}$. At $12,18,24,36,48,72$ and $96 \mathrm{~h}$ after the gametes were mixed, 20 propagules were pipetted from each jar and the number of propagules in each of the following 5 development stages were identified (following Ball et al. 2002): (1) 4-cell blastula, (2) multiple cell blastula, (3) early gastrula, (4) gastrula and (5) planulae (motile stage). The cohorts used in these experiments are listed in the legend to Fig. 2.
To test for differences in development time between treatments, the average time $(\bar{X})$ for propagules to reach a certain stage of development was estimated as follows:

$$
\bar{X}=
$$

$\Sigma$ Time $(\mathrm{h}) \times$ No. of propagules to reach stage $\times(1)$ (Total no. of propagules) $^{-1}$

\section{Effect of temperature and $\mathrm{pCO}_{2}$ on larval survival}

Fifty motile larvae ( $4 \mathrm{~d}$ old) were placed in each of 3 replicate jars with plankton mesh lids and immersed in the treatment tanks. Surviving larvae were counted every $4 \mathrm{~h}$. This period is sufficient for dead larvae to lyse and disappear from the jars (Baird et al. 2006). Larval survival was followed for up to $14 \mathrm{~d}$ in each treatment. The cohorts used in these experiments are listed in the legend of Fig. 4.

\section{Effect of temperature and $\mathrm{pCO}_{2}$ on metamorphosis}

Metamorphosis of Acropora larvae typically peaks between 6 and $10 \mathrm{~d}$ after spawning (Connolly \& Baird 2010). Consequently, $7 \mathrm{~d}$ old larvae were used to test for differences in metamorphosis between treatments. Ten to 20 larvae were pipetted from each of the 12 replicate plastic jars and placed into each well of a 6-well cell culture plate. Consequently, there were 3 replicate 6 -well plates in each treatment with a total of 180 or 360 larvae per treatment. A $2 \times 2 \mathrm{~mm}$ chip of live crustose coralline algae (CCA) (Titanoderma sp.) was placed in each well to induce metamorphosis (Harrington et al. 2004) and the plates were then immersed in the treatments. The lids of the 
6-well plates were modified with plankton mesh to allow treated seawater to mix with the water in the wells. The number of larvae that completed metamorphosis was assessed after $24 \mathrm{~h}$ under a dissecting microscope $(10 \times)$. Metamorphosis was defined as the deposition of a basal disc, which is generally visible through the juvenile coral tissue (Babcock et al. 2003, Baird \& Babcock 2000). The cohorts used in these experiments are listed in the legend of Fig. 5.

\section{Data analysis}

Mean differences among the 4 treatments in the proportion of eggs fertilized, time to complete gastrulation, time to motility, and the number of larvae completing metamorphosis were tested with a fully orthogonal 2-way ANOVA. The factors were Temperature (fixed, 2 levels: 27 and $29^{\circ} \mathrm{C}$ ) and $\mathrm{pCO}_{2}$ (fixed, 2 levels: ambient and elevated $\mathrm{pCO}_{2}$ ). Each assay was analyzed independently (i.e. 2 to 4 assays representing the different cohorts of larvae depending on the response variable). A Bonferroni correction was used to adjust the probability of type I error (i.e. probability was considered significant when beta $<$ alpha/n, where beta equals the Bonferoni corrected probability, alpha $=0.05$ and $n=$ the number of assays run for the specific response variable). Any bias in these data was explored by residual analysis. Response variables were transformed as follows: percent fertilization - no transformation necessary; time to gastrulation and motility - $\log _{10}$ transformed; proportion metamorphosis - arcsine transformed. Differences in the median survival time among treatments for each assay were tested using Kaplan-Meier survival analysis. All statistical analyses were performed using SPSS $16^{\circledR}$.

\section{RESULTS}

The mean proportion of eggs completing fertilization was not affected by either temperature or $\mathrm{pCO}_{2}$ in 3 of the 4 assays. In all these assays, fertilization success was uniformly high (Fig 1A-C). In the Acropora millepora Nov_22 assay, the proportion (mean $\pm \mathrm{SE}$ ) of eggs fertilized was significantly lower at high temperatures $\left(F_{(1,20)}=10.376, \mathrm{p}=0.005\right)$ : $100 \%$ fertilized eggs at $27^{\circ} \mathrm{C}$ versus $89.5 \pm 3.8$ at $29^{\circ} \mathrm{C}$ (Fig. 1D).

The effects of temperature and $\mathrm{pCO}_{2}$ on time to complete gastrulation were variable. In all but one cohort, Acropora millepora Nov_22, embryos completed gastrulation more rapidly at high temperature
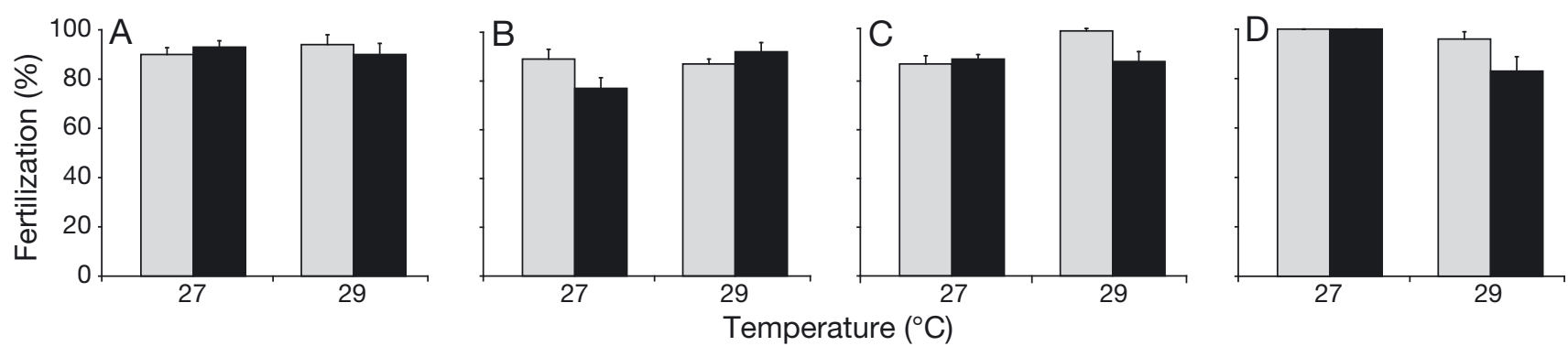

Fig. 1. Fertilization (mean percent $+1 \mathrm{SE}$ ) in 4 combinations of temperature and $\mathrm{pCO}_{2}$. (A) Acropora tenuis, (B) A. millepora Nov_01, (C) A. millepora Nov_02, (D) A. millepora Nov_22. Bars: grey: ambient $\mathrm{pCO}_{2}$, black: high pCO ${ }_{2}$ (values for the levels of each factor are listed in Table 1)
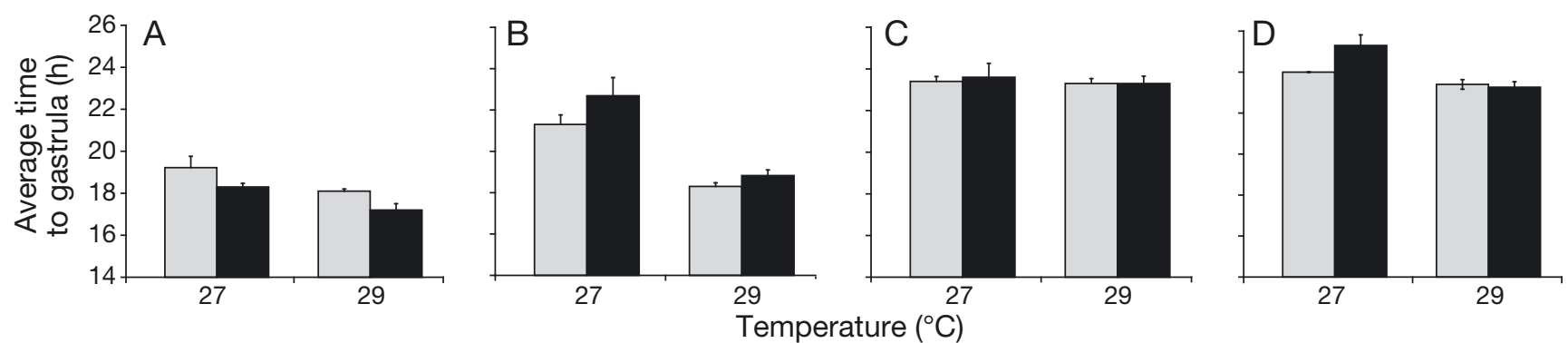

Fig. 2. Time to gastrula stage (mean $+1 \mathrm{SE}$ ) in 4 combinations of temperature and $\mathrm{pCO}_{2}$. (A) Acropora tenuis, (B) A. millepora Nov_01, (C) A. millepora Nov_22, (D) A. millepora Nov_30. For details, see Fig. 1 legend 
Table 2. Two-way ANOVA testing for difference among treatments in the mean time for embryos to develop to the gastrula stage. Data were $\log _{10}$ transformed. Bonferroni corrected probability $=0.013$

\begin{tabular}{|c|c|c|c|c|}
\hline Cohorts & $\mathrm{n}$ & $\mathrm{df}$ & $F$ & $\mathrm{p}$ \\
\hline A. tenuis & 238 & & & \\
\hline Temp & & 1 & 14.475 & $<0.001$ \\
\hline $\mathrm{pCO}_{2}$ & & 1 & 10.067 & 0.002 \\
\hline Temp $\times \mathrm{pCO}_{2}$ & & 1 & 0.696 & 0.405 \\
\hline A. millepora Nov_01 & 232 & & & \\
\hline Temp & & 1 & 50.353 & $<0.001$ \\
\hline $\mathrm{pCO}_{2}$ & & 1 & 2.525 & 0.113 \\
\hline Temp $\times \mathrm{pCO}_{2}$ & & 1 & 0.157 & 0.692 \\
\hline A. millepora Nov_22 & 240 & & & \\
\hline Temp & & 1 & 0.090 & 0.765 \\
\hline $\mathrm{pCO}_{2}$ & & 1 & 0.050 & 0.823 \\
\hline Temp $\times \mathrm{pCO}_{2}$ & & 1 & 0.090 & 0.765 \\
\hline A. millepora Nov_30 & 237 & & & \\
\hline Temp & & 1 & 18.846 & $<0.001$ \\
\hline $\mathrm{pCO}_{2}$ & & 1 & 2.143 & 0.145 \\
\hline Temp $\times \mathrm{pCO}_{2}$ & & 1 & 3.993 & 0.047 \\
\hline
\end{tabular}

(Fig. 2, Table 2). For example, the average time to complete gastrulation in A. millepora Nov_01 was $22.0 \pm 0.49 \mathrm{~h}$ at $27^{\circ} \mathrm{C}$, compared to $18.6 \pm 0.16 \mathrm{~h}$ at $29^{\circ} \mathrm{C}$. In the $A$. tenuis cohort $\mathrm{pCO}_{2}$ also had an effect, with embryos in high $\mathrm{pCO}_{2}$ completing gastrulation more quickly $(17.8 \pm 0.18 \mathrm{~h})$ than those at ambient $\mathrm{pCO}_{2}(18.7 \pm 0.28 \mathrm{~h})$ (Fig. 2A, Table 2). No cohort showed any interaction between temperature and $\mathrm{pCO}_{2}$ (Table 2). Similarly, the effects of temperature and $\mathrm{pCO}_{2}$ on time to motility were variable. In all but one cohort, A. millepora Nov_22, motility was achieved more rapidly at higher temperatures (Fig. 3, Table 3); however, 2 cohorts showed an interaction between temperature and $\mathrm{pCO}_{2}$. In A. tenuis, there was no difference between the $\mathrm{pCO}_{2}$ treatments at $27^{\circ} \mathrm{C}$; however, at $29^{\circ} \mathrm{C}$ motility was reached more rapidly in the high $\mathrm{pCO}_{2}$ treatment (Fig. 3A). In $A$. millepora Nov_01, there was no difference between the $\mathrm{pCO}_{2}$ treatments at $29^{\circ} \mathrm{C}$; however, at $27^{\circ} \mathrm{C}$,
Table 3. Two-way ANOVA testing for difference among treatments in the mean time for embryos to reach motility. Data were $\log _{10}$ transformed. Bonferroni corrected probability $=0.013$

\begin{tabular}{|lrrrr|}
\hline Cohorts & $\mathrm{n}$ & $\mathrm{df}$ & \multicolumn{1}{c|}{$F$} & $\mathrm{p}$ \\
\hline A. tenuis & 142 & & & \\
Temp & & 1 & 323.125 & $<0.001$ \\
$\mathrm{pCO}{ }_{2}$ & & 1 & 4.935 & 0.028 \\
Temp $\times$ pCO $_{2}$ & & 1 & 44.796 & $<0.001$ \\
A. millepora Nov_01 & 218 & & & \\
Temp & & 1 & 53.519 & $<0.001$ \\
pCO & 1 & 10.597 & 0.001 \\
Temp $\times$ pCO $_{2}$ & & 1 & 17.654 & $<0.001$ \\
A. millepora Nov_22 & 142 & & & \\
Temp & & 1 & 3.015 & 0.085 \\
pCO & & 1 & 10.101 & 0.002 \\
Temp $\times$ pCO $_{2}$ & & 1 & 3.622 & 0.059 \\
A. millepora Nov_30 & 210 & & & \\
Temp & & 1 & 13.202 & $<0.001$ \\
pCO & & 1 & 0.070 & 0.792 \\
Temp $\times$ pCO $_{2}$ & & 1 & 0.587 & 0.444 \\
\hline
\end{tabular}

embryos in the high $\mathrm{pCO}_{2}$ treatment became motile more quickly (Fig. 3B). In only one instance there was an effect of just $\mathrm{pCO}_{2}$. In A. millepora Nov_22 motility was reached more rapidly at high $\mathrm{pCO}_{2}$ (Fig. 3C, Table 3) than at ambient $\mathrm{pCO}_{2}(59.2 \pm 1.7 \mathrm{~h}$ vs. $66.8 \pm 2.84$ h) (Fig. 3 C, Table 3 ).

The effects of temperature and $\mathrm{pCO}_{2}$ on larval survivorship were also variable. In Acropora tenuis, median survivorship was significantly lower in the high temperature + ambient $\mathrm{pCO}_{2}$ treatment, but did not vary among the other 3 treatments as indicated by the overlap in the $95 \%$ CIs (Fig. 4A). In A. millepora Nov_22, median survivorship was lower in the high temperature and the combined high temperature high $\mathrm{pCO}_{2}$ treatment when compared to ambient temperature + ambient $\mathrm{pCO}_{2}$ (Fig. 4B); however, there was no significant difference in median survivorship between the high $\mathrm{pCO}_{2}$ treatment and any other treatment (Fig. 4B).
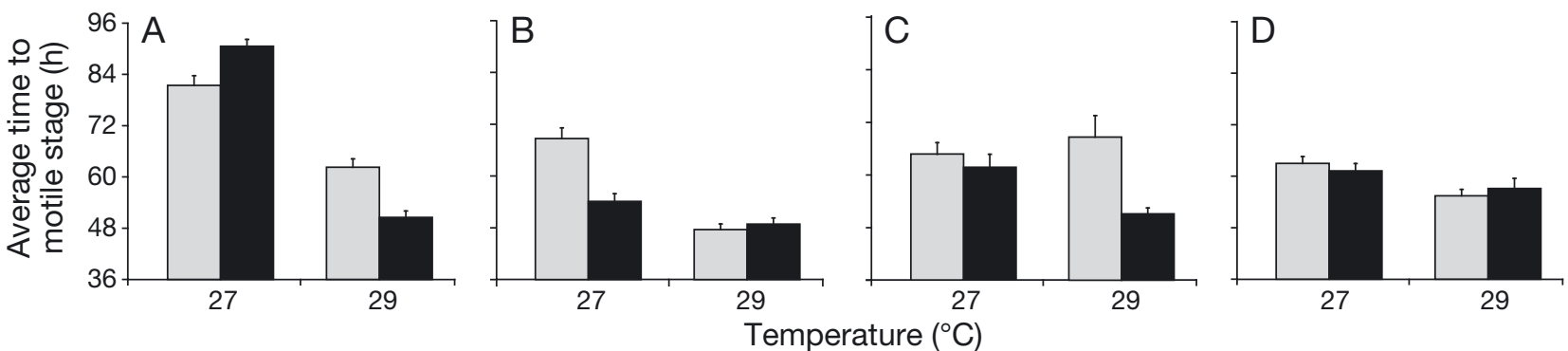

Fig. 3. Time to motile stage (mean $+1 \mathrm{SE}$ ) in 4 combinations of temperature and $\mathrm{pCO}_{2}$. (A) Acropora tenuis, (B) A. millepora Nov_01, (C) A. millepora Nov_22, (D) A. millepora Nov_30. For details, see Fig. 1 legend 


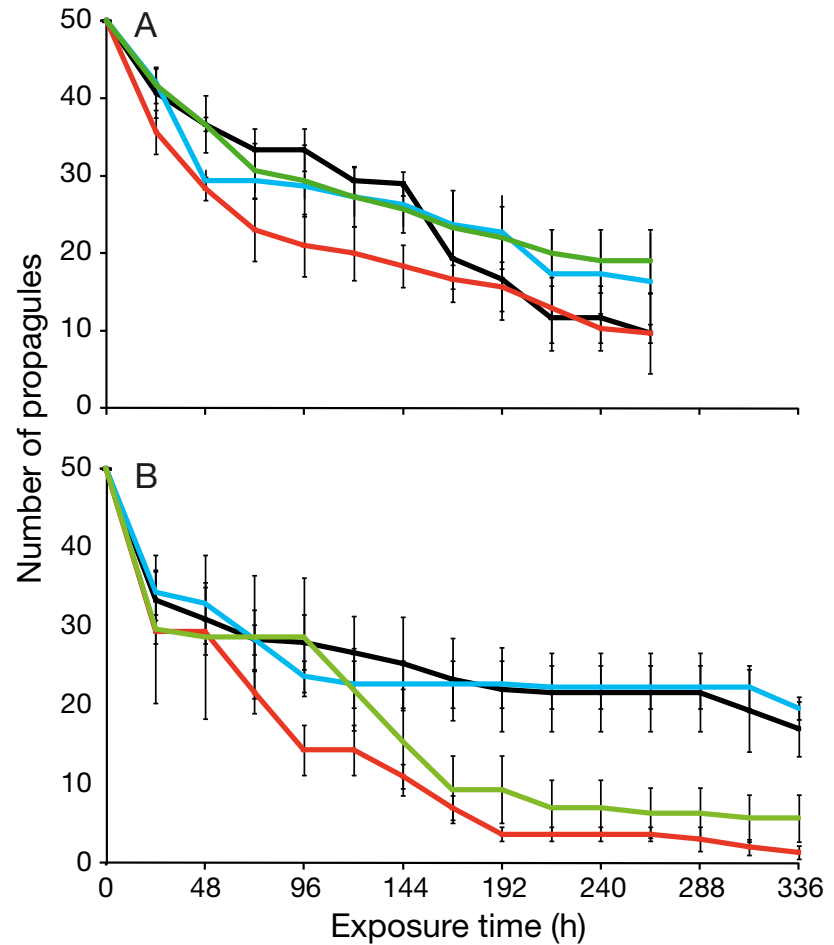

Fig. 4. Number of surviving propagules (median $\pm 95 \%$ CI) estimated using Kaplan-Meier analysis in 4 combinations of temperature and $\mathrm{pCO}_{2}$. (A) Acropora tenuis, (B) A. millepora Nov_22. Black lines: ambient temperature + ambient $\mathrm{pCO}_{2}$; red lines: high temperature + ambient $\mathrm{pCO}_{2}$; blue lines: high $\mathrm{pCO}_{2}+$ ambient temperature; green lines: high temperature + high $\mathrm{pCO}_{2}$ (details on experimental parameters in Table 1)

The effects of temperature and $\mathrm{pCO}_{2}$ on larval metamorphosis were also variable. In $A$. tenuis, metamorphosis was significantly higher at $29^{\circ} \mathrm{C}$ $(55.1 \pm 4.5 \%$ vs. $70.3 \pm 2.5 \%)\left(F_{(1,72)}=7.30, \mathrm{p}=0.009\right.$; Fig. 5A). In contrast, metamorphosis was lower at $29^{\circ} \mathrm{C}$ in Acropora millepora Nov_22 $(54.9 \% \pm 3.0$ vs. $40.2 \% \pm 4.5)\left(F_{(1,72)}=7.24, \mathrm{p}=0.009\right.$; Fig. 5B). $\mathrm{pCO}_{2}$ did not have any effect on metamorphosis, either on its own, or in combination with high temperature.

\section{DISCUSSION}

Increased temperature (by $+2^{\circ} \mathrm{C}$ ) more consistently affected the early life stages of corals in comparison to elevated $\mathrm{pCO}_{2}(\sim 215 \mu$ atm above ambient). In general, rates of development were faster at high temperature, as predicted by metabolic theory (Gillooly et al. 2001). In contrast, elevated $\mathrm{pCO}_{2}$ rarely affected development and, with one exception, only in combination with temperature. However, the effect was contrary to what is generally predicted. In both assays where an interaction was

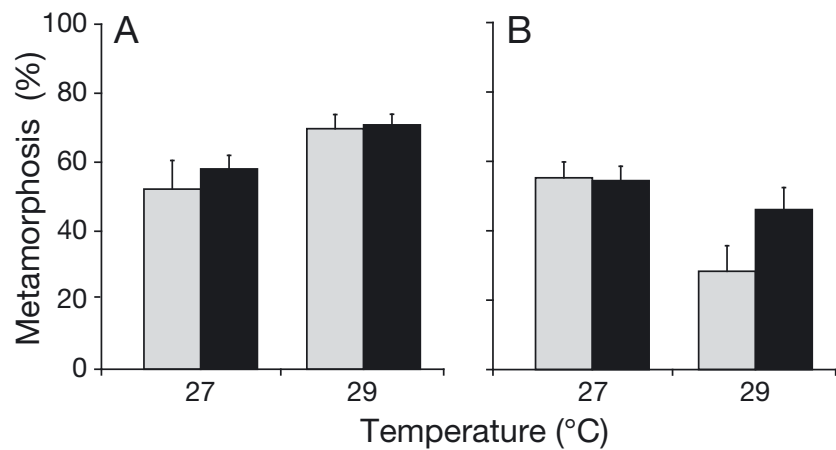

Fig. 5. Percentage of metamorphosis (mean $+1 \mathrm{SE}$ ) in 4 combinations of temperature and $\mathrm{pCO}_{2}$. (A) Acropora tenuis, (B) A. millepora Nov_22. For details, see Fig. 1 legend

detected (Fig. 3A,B, Table 3), high $\mathrm{pCO}_{2}$ decreased the time to motility, whereas elevated $\mathrm{pCO}_{2}$ would be expected to slow rates of development (Pörtner et al. 2004). Similarly, in the only assay where elevated $\mathrm{pCO}_{2}$ had a significant effect on development rates, time to motility was faster in high $\mathrm{pCO}_{2}$ treatments. Neither temperature, elevated $\mathrm{pCO}_{2}$ nor the combination of these variables affected fertilization, larval survivorship or metamorphosis in any consistent or predictable way. We conclude that the changes in temperature and elevated $\mathrm{pCO}_{2}$ projected for this century are unlikely to have major ecological effects on the early life history of corals, either alone or in combination, except that temperature will speed up rates of larval development.

Fertilization was robust to both elevated $\mathrm{pCO}_{2}$ and temperature within the range of variables used in the experiments. This result is in good agreement with most previous work with marine invertebrate larvae (reviewed in Byrne 2011), the exception being Albright et al. (2010) who reported a $64 \%$ decrease in fertilization rates at similar levels of OA, but only when sperm concentration was low. In general, fertilization rates in corals are only reduced at $+4^{\circ} \mathrm{C}$ (e.g. Negri et al. 2007). Similarly, sea urchin fertilization is robust to these levels of elevated $\mathrm{pCO}_{2}$ and temperature (Sheppard Brennand et al. 2010, Byrne 2011). Indeed, marine invertebrate fertilization is generally robust to acidity and minor increases in temperature because the propagules are often equipped with cellular defense mechanisms. These are present in the egg before fertilization (Hamdoun \& Epel 2007, Portune et al. 2010), probably because the gametes are regularly exposed to fluctuating temperature and $\mathrm{pCO}_{2}$ in the water column (Gagliano et al. 2010).

Consistent with the literature (Byrne 2011, Chua 2012), and to be expected on the basis of metabolic theory, rates of development were predictably in- 
creased by temperature. However, it was surprising that elevated $\mathrm{pCO}_{2}$ also on occasion increased rates of development, both on its own and in combination with high temperature, in contrast to a prediction of reduced metabolism from hypercapnia.

Metamorphosis was affected by temperature but not elevated $\mathrm{pCO}_{2}$ i however, the temperature effect was inconsistent. Again, these results are generally consistent with the literature (see Chua 2012). Temperatures of $+2^{\circ} \mathrm{C}$ above ambient levels have little effect on metamorphosis, and both increases (Coles 1985) or decreases (Randall \& Szmant 2009) are evident at temperature elevations $>+2^{\circ} \mathrm{C}$. Metamorphosis is rarely directly affected by elevated $\mathrm{pCO}_{2}$ (Albright et al. 2010, 2011); indeed, Nakamura et al. (2011) reported a direct effect only for larvae that have passed peak metamorphosis. The effect of elevated $\mathrm{pCO}_{2}$ on metamorphosis, if any, is indirect and mediated through elevated $\mathrm{pCO}_{2}$ induced changes in the composition of the substratum, in particular the health of crustose coralline algae that are often required to induce metamorphosis in coral (Albright et al. 2010, Doropoulos et al. 2012). In the only other study on a synergistic effect between these stressors, metamorphosis was not affected (Anlauf et al. 2011).

Survivorship was not consistently affected by elevated $\mathrm{pCO}_{2}$ or temperature. The temperature result is perhaps surprising because most previous experiments report an affect for an elevation of $+2^{\circ} \mathrm{C}$ (e.g. Coles 1985, Bassim \& Sammarco 2003, but see Yakovleva et al. 2009). In contrast, larval survivorship is rarely affected by elevated $\mathrm{pCO}_{2}$ (Suwa et al. 2010, Nakamura et al. 2011). This suggests that some coral species are more susceptible to temperature and elevated $\mathrm{pCO}_{2}$ stress than others (Fabricius et al. 2011).

In conclusion, the effects of $\mathrm{a}+2^{\circ} \mathrm{C}$ increase in temperature were relatively minor and had no effect on fertilization, and mixed effects on larval survivorship and metamorphosis. The only consistent effect was on rates of development, which were typically more rapid at high temperature. The effects of increased rates of development on coral demography are difficult to predict. If larvae develop competence more quickly, average dispersal distance should decrease which is, therefore, likely to reduce levels of reef connectivity (Heyward \& Negri 2010). However, greater levels of retention are also likely to increase the rates of recruitment. Consequently, the effect of more rapid rates of development in response to increasing temperatures are likely to be highly dependent on local conditions such as reef density and hydrodynamics. In contrast to temperature, ele- vated $\mathrm{pCO}_{2}$ had no predictable or consistent effect, either alone, or in combination with temperature. We conclude, that temperature increases associated with global warming are more likely to have ecological consequences than $\mathrm{OA}$ at least in the near-future (see also Cooper et al. 2012).

Acknowledgements. We thank P. Munday for the original design of the $\mathrm{CO}_{2}$ manipulation system and JCU Marine and Freshwater Aquarium research assistants for technical assistance. We thank E. Woolsey, L. Huisman, P. Cross and G. Torda for field assistance and L. Harrington for CCA identification. This project was funded by ARC grants to W.L. and A.H.B. and the Ministry of Higher Education of Malaysia funded the PhD scholarship to C.M.C.

\section{LITERATURE CITED}

Albright R, Mason B, Miller M, Langdon C (2010) Ocean acidification compromises recruitment success of the threatened Caribbean coral Acropora palmata. Proc Natl Acad Sci USA 107:20400-20404

Albright R (2011) Reviewing the effects of ocean acidification on sexual reproduction and early life history stages of reef-building corals. J Mar Biol 2011:473615

Anlauf H, D'Croz L, O'Dea A (2011) A corrosive concoction: the combined effects of ocean warming and acidification on the early growth of a stony coral are multiplicative. J Exp Mar Biol Ecol 397:13-20

Anthony KRN, Kline DI, Diaz-Pulido G, Dove S, HoeghGuldberg O (2008) Ocean acidification causes bleaching and productivity loss in coral reef builders. Proc Natl Acad Sci USA 105:17442-17446

Babcock RC, Baird AH, Piromvaragorn S, Thomson DP, Willis BL (2003) Identification of scleractinian coral recruits from Indo-Pacific reefs. Zool Stud 42:211-226

Baird AH, Babcock RC (2000) Morphological differences among three species of newly settled pocilloporid coral recruits. Coral Reefs 19:179-183

Baird AH, Gilmour JP, Kamiki TM, Nonaka M, Pratchett MS, Yamamoto HH, Yamasaki H (2006) Temperature tolerance of symbiotic and non-symbiotic coral larvae. Proc 10th Int Coral Reef Symp, Okinawa, p 38-42

Baird AH, Bhagooli R, Ralph PJ, Takahashi S (2009) Coral bleaching: the role of the host. Trends Ecol Evol 24:16-20

Ball EE, Hayward DC, Reece-Hoyes JS, Hislop NR and others (2002) Coral development: from classical embryology to molecular control. Int J Dev Biol 46:671-678

Barry JP, Tyrell T, Hansson L, Plattner GK, Gattuso JP (2010) Atmospheric $\mathrm{CO}_{2}$ targets for ocean acidification perturbation experiments. In: Riebesell U, Fabry VJ, Hansson L, Gattuso JP (eds) Guide to best practices for ocean acidification research and data reporting European project on ocean acidification. Publication Office of the European Union, Luxembourg, p 53-64

Bassim KM, Sammarco PW (2003) Effects of temperature and ammonium on larval development and survivorship in a scleractinian coral (Diploria strigosa). Mar Biol 142: 241-252

Bassim KM, Sammarco PW, Snell TL (2002) Effects of temperature on success of (self and non-self) fertilization and embryogenesis in Diploria strigosa (Cnidaria, Sclerac- 
tinia). Mar Biol 140:479-488

Bindoff NL, Willebrand J, Artale V Cazenave A and others (2007) Observations: oceanic climate change and sea level. Intergovernmental Panel on Climate Change. Cambridge University Press, Cambridge

Byrne M (2011) Impact of ocean warming and ocean acidification on marine invertebrate life history stages: vulnerabilities and potential for persistence in a changing ocean. Oceanogr Mar Biol Annu Rev 49:1-42

Chua CM (2012) Effects of ocean acidification and warming on the early life history stages of corals. PhD thesis, James Cook University, Townsville

Coles SL (1985) The effects of elevated temperature on reef coral planula settlement as related to power station entrainment. Proc 5th Int Coral Reef Congr, Tahiti 4: 171-176

Connolly SR, Baird AH (2010) Estimating dispersal potential for marine larvae: dynamic models applied to scleractinian corals. Ecology 91:3572-3583

Cooper TF, O'Leary RA, Lough JM (2012) Growth of western australian corals in the anthropocene. Science 335: 593-596

- Dickson AG, Millero FJ (1987) A comparison of the equilibrium constants for the dissociation of carbonic acid in seawater media. Deep Sea Res A 34:1733-1743

> Doropoulos C, Ward S, Diaz-Pulido G, Hoegh-Guldberg O, Mumby PJ (2012) Ocean acidification reduces coral recruitment by disrupting intimate larval-algal settlement interactions. Ecol Lett 15:338-346

> Dufault AM, Cumbo VR, Fan TY, Edmunds PJ (2012) Effects of diurnally oscillating $\mathrm{pCO}_{2}$ on the calcification and survival of coral recruits. Proc R Soc Lond B Biol Sci 279: 2951-2958

Fabricius KE, Langdon C, Uthicke S, Humphrey C and others (2011) Losers and winners in coral reefs acclimatized to elevated carbon dioxide concentrations. Nature Clim Change 1:165-169

Feely R, Orr J, Fabry V, Kleypas J, Sabine C, Langdon C (2009) Present and future changes in seawater chemistry due to ocean acidification. In: McPherson B, Sundquist E (eds) Carbon sequestration and its role in the global carbon cycle. Geophys Monogr Ser, Vol 183. AGU, p 175-188

Gagliano M, McCormick MI, Moore JA, Depczynski M (2010) The basics of acidification: baseline variability of pH on Australian coral reefs. Mar Biol 157:1849-1856

Gillooly JF, Brown JH, West GB, Savage VM, Charnov EL (2001) Effects of size and temperature on metabolic rate. Science 293:2248-2251

Hamdoun A, Epel D (2007) Embryo stability and vulnerability in an always changing world. Proc Natl Acad Sci USA 104:1745-1750

> Harrington L, Fabricius K, De'Ath G, Negri A (2004) Recognition and selection of settlement substrata determine post-settlement survival in corals. Ecology 85:3428-3437

> Heyward AJ, Negri AP (2010) Plasticity of larval pre-competency in response to temperature: observations on multiple broadcast spawning coral species. Coral Reefs 29: 631-636

> Langdon C, Atkinson MJ (2005) Effect of elevated $\mathrm{pCO}_{2}$ on photosynthesis and calcification of corals and interactions with seasonal change in temperature/irradiance and nutrient enrichment. J Geophys Res 110:C09S07, doi:10.1029/2004JC002576

McClanahan TR, Weil E, Cortés J, Baird AH, Ateweberhan M (2009) Consequences of coral bleaching for sessile reef organisms. In: van Oppen MJH, Lough JM (eds) Coral bleaching. Springer, Berlin, p 121-138

> Mehrbach C, Culberson CH, Hawley JE, Pytkowicz RM (1973) Measurement of the apparent dissociation constants of carbonic acid in seawater at atmospheric pressure. Limnol Oceanogr 18:897-907

Munday PL, Dixson DL, Donelson JM, Jones GP, Pratchett MS, Devitsina GV, Døving KB (2009) Ocean acidification impairs olfactory discrimination and homing ability of a marine fish. Proc Natl Acad Sci USA 106:1848-1852

Nakamura M, Ohki S, Suzuki A, Sakai K (2011) Coral larvae under ocean acidification: survival, metabolism, and metamorphosis. PLoS ONE 6:e14521

> Negri AP, Marshall PA, Heyward AJ (2007) Differing effects of thermal stress on coral fertilization and early embryogenesis in four Indo Pacific species. Coral Reefs 26: 759-763

Nesa B, Baird AH, Harii S, Yakovleva I, Hidaka M (2012) Algal symbionts increase DNA damage in coral planulae exposed to sunlight. Zool Stud 51:12-17

O'Connor MI, Piehler MF, Leech DM, Anton A, Bruno JF (2009) Warming and resource availability shift food web structure and metabolism. PLoS Biol 7:e1000178

> Oliver J, Babcock R (1992) Aspects of fertilization ecology of broadcast spwaning corals - sperm dilution effects and in-situ measurements of fertilization. Biol Bull 183: 409-417

Pandolfi JM, Connolly SR, Marshall DJ, Cohen AL (2011) Projecting coral reef futures under global warming and ocean acidification. Science 333:418-422

Pierrot D, Lewis E, Wallace D (2006) MS Excel program developed for $\mathrm{CO}_{2}$ systems calculations. Carbon Dioxide Information Analysis Center, Oak Bridge National Laboratory, US Department of Energy, Oak Ridge, TN

Pörtner HO, Langenbuch M, Reipschlager A (2004) Biological impact of elevated ocean $\mathrm{CO}_{2}$ concentrations: lessons from animal physiology and earth history. J Oceanogr 60: $705-718$

> Portune KJ, Voolstra CR, Medina M, Szmant AM (2010) Development and heat stress-induced transcriptomic changes during embryogenesis of the scleractinian coral Acropora palmata. Mar Genomics 3:51-62

Randall C, Szmant A (2009) Elevated temperature reduces survivorship and settlement of the larvae of the Caribbean scleractinian coral, Favia fragum (Esper). Coral Reefs 28:537-545

> Sheppard Brennand H, Soars N, Dworjanyn SA, Davis AR, Byrne $M$ (2010) Impact of ocean warming and ocean acidification on larval development and calcification in the sea urchin Tripneustes gratilla. PLoS ONE 5:e11372

- Suwa R, Nakamura M, Morita M, Shimada K, Iguchi A, Sakai K, Suzuki A (2010) Effects of acidified seawater on early life stages of Scleractinian corals (genus Acropora). Fish Sci 76:93-99

Yakovleva IM, Baird AH, Yamamoto HH, Bhagooli R, Nonaka M, Hidaka M (2009) Algal symbionts increase oxidative damage and death in coral larvae at high temperatures. Mar Ecol Prog Ser 378:105-112

Submitted: May 9, 2012; Accepted: September 26, 2012 Proofs received from author(s): January 24, 2013 